\title{
Structural model of university social responsibility
}

\section{Modelo estructural de responsabilidad social universitaria}

\author{
Carlos Francisco Ortiz-Paniagua ${ }^{\mathrm{a}}$ \\ Joel Bonales Valenciab \\ Araceli Flores Esparzac
}

\begin{abstract}
${ }^{a}$ PhD in Regional Development Science, Full-Time Professor and Researcher, Universidad Michoacana de San Nicolás de Hidalgo, Mexico E-mail:carlos.ortiz@umich.mx
\end{abstract}

${ }^{b}$ PhD in Administrative Sciences, Full-Time Professor and Researcher, Universidad Michoacana de San Nicolás de Hidalgo, Mexico E-mail: joel.bonales@umich.mx

' Master in Management, Part-Time Professor, Universidad Michoacana de San Nicolás de Hidalgo, Mexico E-mail: araceli.flores@umich.mx

doi:10.18472/SustDeb.v12n2.2021.37345

\section{ABSTRACT}

The study aims to analyze the University Social Responsibility (USR) policy implemented at the Michoacan State University (Universidad Michoacana de San Nicolás de Hidalgo - UMSNH) from the perspective of the university community. For that purpose, a Structural Equations Model in its variant of Partial Least Squares (PLS) was used from a theoretical/empirical construct on the USR. Five variables integrated into 17 indicators were used, obtained by a representative sample. The results are presented in two sections; a) USR performance at the UMSNH and; b) the role of each variable in the PLS model. It is concluded that the performance was regular and the Internal Management (IM) had a key impact on the model operation. In the management practice, this might help identify areas to improve the performance of this policy by sector and variables.

Keywords: University Social Responsibility. Sustainable Development. USR Institutional Performance. Partial Least Square. 


\section{RESUMEN}

El objetivo del estudio fue analizar la política de Responsabilidad Social Universitaria (RSU) implementada en la Universidad Michoacana de San Nicolás de Hidalgo (UMSNH) desde la perspectiva de la comunidad universitaria. Para ello se empleó un Modelo Estructural de Mínimos Cuadrados Parciales (PLS) a partir de un constructo teórico/empírico sobre la RSU. Se emplearon cinco variables integradas en 17 indicadores, obteniendo la información mediante una encuesta a una muestra representativa. Los resultados se presentan en dos apartados: a) descripción sobre el desempeño de la RSU en la UMSNH y; b) rol de cada variable en el modelo PLS. Se concluye que el desempeño de la RSU fue regular y que la Gestión Organizacional (GO) tuvo un impacto clave en el funcionamiento del modelo. En la practica administrativa, esto podría ayudar a identificar áreas de oportunidad para mejorar el desempeño de esta política por sectores y variables.

Palabras clave: Responsabilidad Social Universitaria. Desarrollo Sustentable. Desempeño Institucional. Partial Least Square. Universidad Michoacana de San Nicolás de Hidalgo.

\section{INTRODUCTION}

The University Social Responsibility (USR) has been established as a comprehensive management policy. It highlights internal processes and promotes good practices to respond to organizational and socio-environmental impacts of the university. It is distinct from the traditional solidarity extension as a unilateral declaratory commitment, compelling each university to put its epistemic assumptions and hidden curriculum under consideration (VALLAEYS, 2007).

Located in Michoacan, Mexico, the Universidad Michoacana de San Nicolás de Hidalgo (UMSNH) began, in 2007, an environmental management model called Institutional Environmental Plan. In 2014 it formally established the concept of the USR, as a result of a postgraduate course lead by Dr François Vallaeys, in which continuous improvement lines, USR program activities and permanent training plans were established (LÓPEZ, M. T. V.; LÓPEZ, M. V., 2016, p. 3).

It is assumed the possibility USR policy impacts differently on each university actor but might show a general trend. Structural analysis can reveal the impact of variables and by university sectors in the performance of the USR policy. The aims of this study are: 1) quantify the performance of the USR, by sectors and as a whole, and 2) analyze the impact by variables. For this purpose, a Partial Least Squares (PLS) analysis was performed. The proposed variables were: Environmental Resource Management (ERM), Internal Management (IM), Social Responsibility Training (SRT), University Social Projection (USP) and; Knowledge Production and Management (KPM).

To accomplish the objectives, the present article is integrated into five sections. The first one examines the concept of the USR and sustainable development, followed by the USR background in the UMSNH. In the third section, the information-gathering techniques and instruments used are explained. Then, in the fourth section, the results were presented, and finally, the conclusions are highlighted.

\section{SUSTAINABLE DEVELOPMENT AND THE USR}

Sustainable development has been a point of reference for social aspirations and it is generally a fundamental part of development policy discourses. However, the environmental crisis continues to move forward and the strategies to restrain it have been insufficient. The USR proposes to go beyond the attention to the negative environmental impacts and collates with sustainable development. This section presents theoretical literature and case studies. It begins with a description of the socioenvironmental crisis and reflects critically on the scope of the USR. 
The current socio-environmental crisis has been the result of social, political and economic interactions of capitalism that have accelerated the trends of ecological degradation and social conflicts over natural resources, as well as causing an increase in poverty, ignorance and injustice, which represents a threat to world prosperousness, security and stability, increasing social conflicts in different areas. Public and private actions have been towards disengagement between the practice of ecological policy and socio-environmental accounting (EARTH CHARTER, 2000; FOLADORI; TALKS, 2001; MARTÍNEZ, 2008; MURGA-MENOYO, 2009; QUINCHÉ-MARTÍN; CABRERA-NARVÁEZ, 2020; TOMMASINO, LEFF, 2002).

Some of the approaches to the socio-environmental crisis, propose paradigm shifts towards environmental rationality (LEFF, 2002). Meanwhile, the USR responds to this crisis from universities as active actors with a key role in development due to the presence and impacts on the stakeholders (VALLAEYS; CARRIZO, 2006). Thus, it is proposed that the university should continuously improve the organizational structure, being part of a transparency system, under the scheme that education and public awareness are key to leading society to achieve sustainability (CHIRINOS; PÉREZ, 2016; FUENTES; VALLAEYS; CASTRILLÓN, 2018; MCKEOWN et al., 2002). However, the university organizational structures are mostly too rigid to undertake profound changes both in the short and medium terms.

The criteria used for the USR management has considered three levels: 1) internal, (students, professors, researchers, authorities and administrative staff); 2) external, (employers, graduate students, suppliers and direct strategic partners) and, 3) global environment, (trends and general interactions) (GASCA; OLVERA, 2011). Thus, the USR and sustainable development promote a university projection that considers dissemination criteria, practice, principles and values in management, teaching, research and extension, reexamining its actions in a new social, ethical, democratic, equitable, transparent, helpful and self-organizing project (ESCUTIA; MEJÍA, 2011; NÚÑEZ, 2013; VALLAEYS, 2013; VALLAEYS; CARRIZO, 2005), assumed as Social Responsibility Training.

Hense, the responsible management of environmental resources is key, under the challenge of mainstreaming the curricular content of the courses and the pedagogical guidelines for the university community. Which was demonstrated in academic training, fostering changes in socially responsible behaviour in students being consciously manifested in emotional, cognitive and empathic processes, concerned and capable of taking the perspective of others (ARANGO et al., 2014). In this sense, the University promotes the education of public awareness, and an indisputable moral and existential commitment in the promotion of sustainable development, beginning with the encouragement of justice, freedom and social equality based on its substantive functions.

Some cases stand out such as, the Universidad de Francisco de Vitoria (Spain) which has incorporated a social responsibility subject into the study program since 1993, showing a significant impact from the students, concerning the social commitment towards others, the environment and the professional practice (RAMOS et al., 2016). In Perú, a study among 18 universities shows that the influence of the USR on the organizational culture, at the moment, has had little impact, which may be due to the lack of the USR program's transversality. However, the variables: teaching-learning, research, technological development and innovation, do show incidence (LIMO; PEÑA, 2019). The challenges range from changes in focus towards the learner, (which questions the common practice), to the teaching practice itself and the motivation in training and the transference of values, highly correlated with the motivation and demoralization of professors (IZARRA, 2019; YURÉN; GARCÍA; BRISEÑO, 2019).

At the Universidad de León in Spain, the impacts of university students and their satisfaction regarding the USR were analyzed. Using a Partial Least Squares (PLS) model, with 46 items in four variables, it was found that students can differentiate the facets of the USR, but only the Internal Management (IM) affected the general perception of the USR. Meanwhile, the global perception of the USR was also a determining factor in students' satisfaction (VÁZQUEZ; AZA; LANERO, 2016). 
Thus, higher education institutions play a fundamental role in influencing society through their own human resource training strategies. In Brazil, entrepreneurial culture and student satisfaction are related in a positive and highly significant manner to the USR, using 11 indicators for student satisfaction, seven for entrepreneurial culture and 26 for the USR, through PLS analysis (SÁNCHEZ-HERNÁNDEZ; MAINARDES, 2016).

From the overhaul made, some reflections can be extracted:

I. Universities play a prominent role in influencing the solution of the current socio-environmental crisis. However, the scope is still limited related to circles of influence, generally young adults, less in childhood, adolescence and trained professionals. Therefore, the USR should also recommend a greater spectrum of action and social scope.

II. The universities' organizational structures are generally rigid and with little possibility of responding to social changes in the short term. Although the USR has been gradually positioned, it is not the rule but the exception.

III. Under this context, the USR proposes changes in behaviour that range from the continuous questioning of habits in the socio-environmental impact to the capitalist logic of seeking alternatives and new paradigms. However, the universities' own internal socio-political dynamics, make it difficult to internalize the USR and/or different policies that recommend changes, which operate when the external environment and favourable internal circumstances continually excerpt pressure.

IV. It is important to think over the need to overcome committed volunteering towards more mandatory schemes, as is already recommended for Social Responsibility Management. The implementation of legal frameworks and public policies capable of orienting markets towards responsible production and consumption, which do not systematically cause negative impacts, go through the law first before goodwill. Rather than a mandatory scheme, a global economic reorientation should be made, with commitments to sustainability (VALLAEYS, 2020).

Finally, some incidental elements in the USR can be highlighted: 1) Environmental Resource Management (ERM); 2) Internal Management (IM); 3) Social Responsibility Training (SRT); University Social Projection (USP) and Knowledge Production and Management (KPM) for the USR. After five years of having implemented the USR in the UMSNH, the proposed hypothesis is that through a PLS structural model, the interaction between variables and actors could be identified, so that the indicators that most influenced the implementation of the Nicolaita USR could be known.

\section{BACKGROUNDS - THE USR IN THE UMSNH}

In the actions taken by the UMSNH's environmental management agenda, these stand out: 1) electrical waste management since 2012, (Recoelectrón); 2) ecological footprint analysis in the UMSNH, as an environmental education mechanism; 3) USR actor training Diploma course is offered, being the professors a key part in all substantive activities (PÉREZ; VALLAEYS, 2016). Additionally, the UMSNH has participated with: 1) the Regional Observatory of Social Responsibility in Latin America and the Caribbean (ORSALC-UNESCO); 2) the founding of the Mexican Observatory of University Social Responsibility (OMERSU); 3) Venue of the First Meeting of Social Responsibility in Mexican Universities (GARCÍA, E. S.; GARCÍA, R. F., 2014); 4) in 2016 it formalized the First Committee for Regional Development and Social Responsibility of the Central West Region of ANUIES and; 5) in 2017, the UMSNH hosted the Second USR International Forum (GARCÍA; AGUILAR, 2017). 


\section{MATERIALS AND METHODS}

The population under study was the UMSNH, 2017 from the registration in the official database, a sample of the following 26 university faculties was obtained; School of Medicine, Dentistry, Pharmacology, Psychology, History, Literature, Law, Fine Arts, Economics, Accounting, Veterinary Medicine, Civil Engineering, Philosophy, Mechanical Engineering, Chemical Engineering, Electrical Engineering, Wood Technology Engineering, Architecture, Biology, Physical Mathematics, Nursing; Institutes of Mechanical Engineering, Natural Resources Research and Agricultural and Forestry Research.

The studied sectors were: authorities, academics, administrative staff and students enrolled in 2017. The sample was obtained from the database provided by the UMSNH Human Resources Department and the Student Services Department. The sample size was obtained from the formula, $n=(Z \wedge 2$ $\mathrm{pqN}) /\left((\mathrm{NE})^{\wedge} 2+\mathrm{Z}^{\wedge} 2 \mathrm{pq}\right.$ ) (Table 1), (values for the sample, $Z=1.96 ; p=0.5 ; \mathrm{q}=0.5 ; E=0.05$ ). As the effective sample, it consists of the number of interviews obtained, which maintain an acceptable level of significance and representativeness.

Table 1 | Universe, population and study sample

\begin{tabular}{ccccc}
\hline Universes & Population & $\begin{array}{c}\text { Minimum } \\
\text { sample size }\end{array}$ & Effective simple & Value of Z \\
\hline Authorities & 130 & 26 & 16 & $12 \%$ from total* \\
\hline Professors & 2,445 & 332 & 226 & 1.60 \\
Students & 36,121 & 380 & 383 & 1.96 \\
Administrative staff & 799 & 259 & 205 & 1.65 \\
\hline Total population & 39,495 & 991 & 705 & \\
\hline
\end{tabular}

*For small populations, a sample slightly greater than $10 \%$ of the population was obtained.

Source: Own elaboration based on the UMSNH Human Resource Department and the Student Services Department, 2017.

\subsection{VARIABLES AND SURVEY DESIGN}

From the study and the analysis of the USR variables and indicators used in other studies (ARANGO et al., 2014; AUSJAL, 2009; CANTÚ, 2013; GASCA; OLVERA, 2011; IESALC, 2008; IZARRA, 2019; LIMO; PEÑA; 2019; RAMOS et al., 2016; VALLAEYS; CARRIZO, 2006), the USR at the UMSNH, comprises five areas: environmental, organizational, educational, social and knowledge. The variables used were: Environmental Resource Management (ERM) (four indicators); Internal Management (IM) (four indicators); Knowledge Production and Management (KPM) (three indicators); Social Responsibility Training (SRT) (four indicators) and University Social Projection (USP) (two indicators) (Table 2).

For data collection, a personal interview questionnaire was used and the design established for the final version of the measurement instrument was integrated into three sections: 1) folio number, the universe and the research name; 2) respondents' profile, varying according to the universe and 3) variables, indicators, their respective items and the measuring scale by intervals (Likert-type scale).

To estimate the questionnaire's reliability, Cronbach's alpha coefficient $(\boldsymbol{\alpha})$ was used, showing consistency for the four measurement instruments in the pilot test. The results of $\boldsymbol{\alpha}$ were: excellent in professors (0.943), administrative staff (0.915) and students (0.927); and acceptable in authorities (0.782) (BOJÓRQUEZ et al., 2013; GONZÁLEZ; PAZMIÑO, 2015). Once the instrument was verified, the data was obtained by applying face-to-face interviews by sectors: authorities, professors, administrative staff and students, with a response time between 10 and 15 minutes. 


\subsection{PARTIAL LEAST SQUARES USE (PLS) TECHNIQUE}

The research was supported by the Structural Equation Modeling (SEM) that allows multiple regressions between latent variables (BARROSO; CEPEDA; ROLDÁN, 2005). To develop the methodological process of the tools' conditions and applicability for multivariate analysis (LÉVY; VARELA, 2003), it was decided to use the PLS modelling which is more appropriate for the prediction of the variables, high complexity and theory development (exploratory analysis) (CHIN, 2010). The variance of the dependent variables explained by the independent variables is maximized, instead of reproducing the empirical covariance matrix (HAENLEIN; KAPLAN, 2004). Furthermore, since the focus estimates the latent variables as linear combinations of the measurements.

These models identify how internal and external factors affect the analyzed variables, considering the way these variables could be interrelated. The PLS assumes that each construct plays the role of a theoretical concept represented by indicators, and the relationships between constructs must be established taking into account the prior knowledge (theory) of the phenomenon under analysis (LOEHLIN, 1987). The PLS is based on an iterative algorithm and the parameters are calculated by Least Squares regressions. The term Partial is due to the iterative procedure that involves separating the parameters instead of estimating them simultaneously (BATISTA-FOGUET; COENDERS, 2000; HAENLEIN; KAPLAN, 2004; ROLDÁN; SÁNCHEZ-FRANCO, 2012).

With the obtained results, a model is built that allows us to see the interrelationships between the USR variable, focusing on maximizing the variance. The results identify the factors that most impact each of the indices, thereby supporting the decision taken by knowing the impact by variable.

\subsection{LATENT AND OBSERVED VARIABLES}

One of the most relevant concepts for SEM is latent variables. These are not directly observable or measured by a generally accepted instrument (SCHUMACKER; LOMAX, 2004). Latent variables are constituted of manifest variables, observed variables or indicators. In the PLS Path Modeling, the latent variables will be obtained as a linear combination of the observed group variables (indicators) (LOEHLIN, 1987). It is assumed that any measurement will be imperfect, as shown (HAENLEIN; KAPLAN, 2004), each observation in the real world comes with a measurement error compound by two parts: (a) random error (caused by the order of the items in a survey or by the respondent bias); and (b) systematic error, due to the variance. Therefore, the observed value of an item is constituted by: 1) the variable's true value; 2 ) the random error and, 3) the systematic error.

The PLS provides a framework for analyzing multiple relationships between constructs. It is assumed that each construct plays the role of a theoretical concept represented by its indicators, and the relationships between constructs must be established taking into account the prior knowledge (theory) of the phenomenon under analysis. In summary, the PLS can be a powerful tool due to the minimum demands of measurement scales, sample size, and residual distributions (CHIN, 2010). To develop the methodological process, the following survey was developed based on the variables, see Table 2 .

The results obtained from the indicators were incorporated by dimension in the PLS smart 3.0 software, grouping by dimensions and variables. Then, a form of relationship between variables is suggested, generating the latent variables based on the expected relationship between them. The following step is to run the interaction in the proposed relationship, the application makes the calculations until it reaches the variable convergence or stability. After several tests, the statistical consistency indicates the model reliability and the interpretation capacity in the integrated variables modelling by the groups of indicators. 
Table 2 | Variables Operationalization

\begin{tabular}{|c|c|c|c|}
\hline Variables & Dimensions & Indicators & Clave \\
\hline \multirow{16}{*}{$\begin{array}{l}\text { Environmental } \\
\text { Resource } \\
\text { Management } \\
\text { (ERM) }\end{array}$} & \multirow{3}{*}{ Ecosystem Protection } & Institutional Environmental Plan (EPI) Knowledge & PE \\
\hline & & Green areas sufficiency & PE2 \\
\hline & & Green areas protection and carefulness & PE3 \\
\hline & \multirow{3}{*}{ Waste Management } & Recycling bin for solid waste separation & MRA1 \\
\hline & & Solid waste sorting knowledge & MRA2 \\
\hline & & Solid waste correct disposal & MRA3 \\
\hline & \multirow{2}{*}{ Energy Use } & Efficient use of energy & UE1 \\
\hline & & Energy generation & UE2 \\
\hline & \multirow{2}{*}{$\begin{array}{c}\text { Water Treatment and } \\
\text { Care }\end{array}$} & Efficiency in the water use & TCA1 \\
\hline & & Water care & TCA2 \\
\hline & \multirow{6}{*}{$\begin{array}{c}\text { Influence in Ecological } \\
\text { Behaviors }\end{array}$} & Paper sheets reuse & ICE1 \\
\hline & & Ecological footprint knowledge & ICE2 \\
\hline & & Low impact mobility promotion & ICE3 \\
\hline & & Disposable reduction & ICE4 \\
\hline & & Influence of the EPI on ecological habits & ICE5 \\
\hline & & Efficient use of water & ICE6 \\
\hline \multirow{9}{*}{$\begin{array}{l}\text { Internal } \\
\text { Management } \\
\text { (IM) }\end{array}$} & \multirow{2}{*}{ Nicolaita Identity } & Attention to vulnerable population & IN1 \\
\hline & & The practice of the principle of humanism & IN2 \\
\hline & \multirow{2}{*}{ Work Environment } & Study environment & AL1 \\
\hline & & Regarding diversity & AL2 \\
\hline & \multirow{3}{*}{$\begin{array}{c}\text { Remuneration and } \\
\text { Training }\end{array}$} & Perception of equity & RC1 \\
\hline & & Perception regarding salary/remuneration & RC2 \\
\hline & & USR training & RC3 \\
\hline & & Democratic values perception & PD1 \\
\hline & $\begin{array}{l}\text { Participation and } \\
\text { Democracy }\end{array}$ & Gender equality & PD2 \\
\hline \multirow{8}{*}{$\begin{array}{c}\text { Social } \\
\text { Responsibility } \\
\text { Training } \\
\text { (SRT) }\end{array}$} & \multirow{2}{*}{ USR Training } & Environmental content & CRS1 \\
\hline & & Contingency strategies training & CRS2 \\
\hline & $\begin{array}{l}\text { Multidisciplinary } \\
\text { Training }\end{array}$ & Social project training & FM1 \\
\hline & \multirow{2}{*}{$\begin{array}{l}\text { Interinstitutional } \\
\text { Training }\end{array}$} & Inclusion in university projects & Fl1 \\
\hline & & Project participation with other universities & $\mathrm{FI} 2$ \\
\hline & \multirow{3}{*}{$\begin{array}{l}\text { Critical Reflection } \\
\text { Training }\end{array}$} & Social problems awareness & FR1 \\
\hline & & Profession role in society & FR2 \\
\hline & & Perception of accomplishment & FR3 \\
\hline \multirow{4}{*}{$\begin{array}{l}\text { University } \\
\text { Social } \\
\text { Projections } \\
\text { (USP) }\end{array}$} & \multirow{2}{*}{ Extension } & Link with environmental causes & EX1 \\
\hline & & Participation in environmental causes & EX2 \\
\hline & \multirow{2}{*}{ Academic Linkage } & Links with deprived sectors of society & VN1 \\
\hline & & University job bank & VN2 \\
\hline \multirow{6}{*}{$\begin{array}{l}\text { Knowledge } \\
\text { Production } \\
\text { and } \\
\text { Management } \\
\text { (KPM) }\end{array}$} & \multirow{2}{*}{$\begin{array}{l}\text { Socially Useful and } \\
\text { Relevant Research }\end{array}$} & The research applied to vulnerable social groups & IP1 \\
\hline & & General research linkage & IP2 \\
\hline & \multirow{2}{*}{$\begin{array}{l}\text { Multidisciplinary } \\
\text { Knowledge }\end{array}$} & Development projects with other sectors & CM1 \\
\hline & & Student/professors participation in research & CM2 \\
\hline & \multirow{2}{*}{$\begin{array}{l}\text { Sustainability } \\
\text { Knowledge }\end{array}$} & Self-knowledge promotion & CS1 \\
\hline & & The research applied to improve USR & CS2 \\
\hline
\end{tabular}

Source: Information obtained from the theoretical framework. 


\section{RESULTS}

\subsection{NICOLAITA USR PERFORMANCE}

The USR performance in the UMSNH, on a scale with a maximum of 5.0, for authorities was 3.57, for professors 3.25 and very close to 3.0 for both administrative staff and students. The average indicates regular performance. The IM shows the best performance (3.6) and the lowest variance (0.022), while the lowest performance was for SRT and USP, both with a value of 3.0. (Table 3). Table 4 shows the global performance by sectors of the parametric statistics where the central tendency and distribution measures can be observed, finding the highest performance for AUT and the lowest for AS, very close to ST, as well as the highest variance among the professors' sector (PF).

Table 3 | USR-UMSNH Average Performance

\begin{tabular}{|c|c|c|c|c|c|c|}
\hline & $\begin{array}{c}\text { Administrative } \\
\text { Staff (AS) }\end{array}$ & Professors (PF) & $\begin{array}{c}\text { Authorities } \\
\text { (AUT) }\end{array}$ & Students (ST) & Average** & Variance \\
\hline$E R M$ & 2.99 & 3.02 & 3.35 & 3.08 & 3.111 & 0.027 \\
\hline$I M$ & 3.54 & 3.66 & 3.84 & 3.52 & 3.641 & 0.022 \\
\hline$S R T$ & 2.78 & 3.07 & 3.14 & 3.05 & 3.012 & 0.026 \\
\hline USP & 2.90 & 3.20 & 3.63 & 2.59 & 3.077 & 0.197 \\
\hline$K P M$ & 3.14 & 3.30 & 3.89 & 2.99 & 3.328 & 0.154 \\
\hline Average* & 3.07 & 3.25 & 3.57 & 3.04 & & \\
\hline Variance & 0.088 & 0.064 & 0.102 & 0.110 & & \\
\hline
\end{tabular}

Table 4 | Descriptive statistics for the global average performance of USR

\begin{tabular}{|c|c|c|c|c|}
\hline & $A S$ & $A \cup T$ & $P F$ & $S T$ \\
\hline Media* & 3.089 & 3.545 & 3.225 & 3.128 \\
\hline Typical error & 0.042 & 0.094 & 0.044 & 0.032 \\
\hline Median & 3.073 & 3.586 & 3.214 & 3.150 \\
\hline Mode & 2.805 & 3.857 & 3.238 & 3.125 \\
\hline Standard deviation & 0.605 & 0.374 & 0.656 & 0.624 \\
\hline Sample variance & 0.366 & 0.140 & 0.430 & 0.390 \\
\hline Kurtosis & -0.367 & 1.802 & -0.665 & -0.153 \\
\hline Asymmetry coefficient & 0.179 & -1.254 & 0.090 & -0.156 \\
\hline Range & 2.951 & 1.429 & 2.857 & 3.625 \\
\hline Minimum & 1.83 & 2.57 & 1.86 & 1.30 \\
\hline Maximum & 4.78 & 4.00 & 4.71 & 4.93 \\
\hline Sum & 633.27 & 56.71 & 728.93 & 1198.18 \\
\hline Observation (n) & 205 & 16 & 226 & 383 \\
\hline
\end{tabular}

* Average from the concentrated information

Source: Own elaboration with field data. 


\subsection{PLS-SEM MODEL FOR THE NICOLAITA USR PERFORMANCE}

A three-step process was followed for the PLS use: 1) the weights of the relationships, which link the indicators to their respective latent variables and are estimated; 2 ) the case values are calculated for each latent variable based on the indicators weighted average; 3) these case values are used in a group of regression equations to determine the parameters of the path or structural coefficients (HAENLEIN; KAPLAN, 2004). The algorithm returns to the relations of the measurement model where new weights (outer weights) are calculated and the process continues iteratively until the convergence of the weights is reached. See Figure 1.

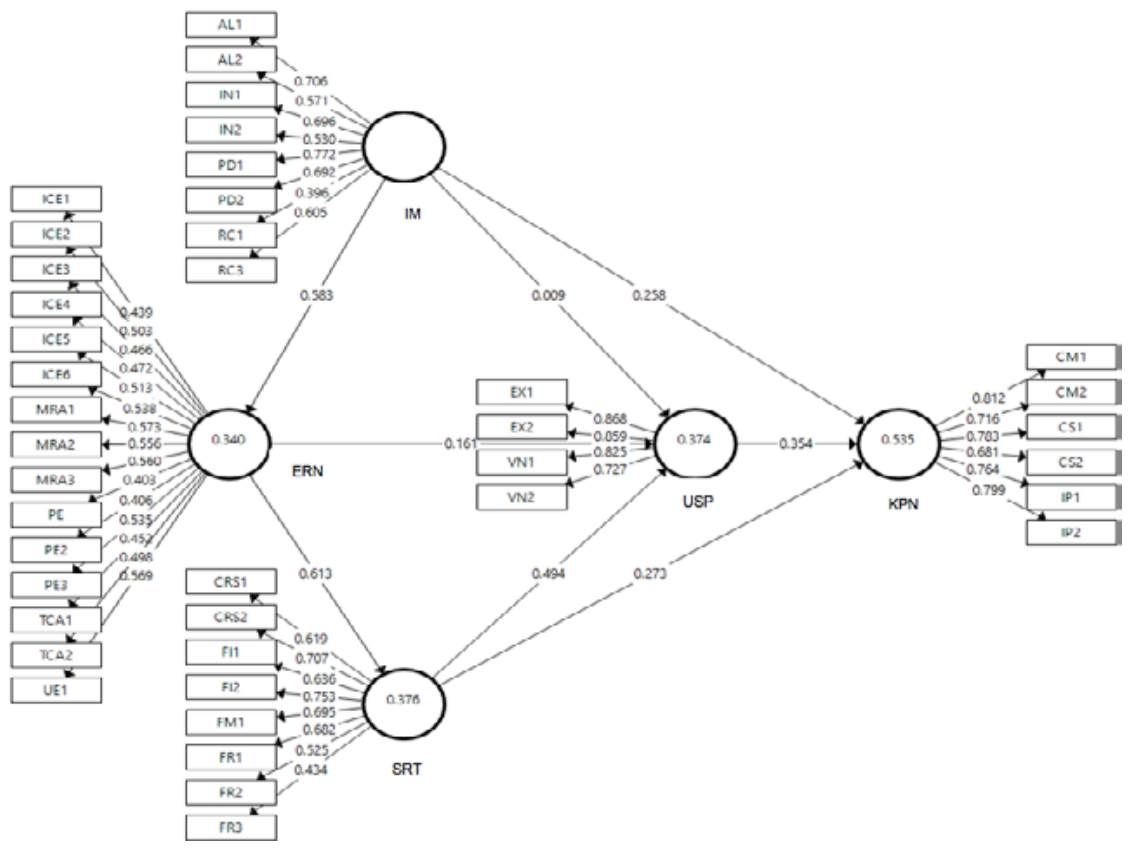

Figure 1 | UMSNH University Social Responsibility Structural Model Source: Personal elaboration in Smart PLS, V. 3.0, based on field information.

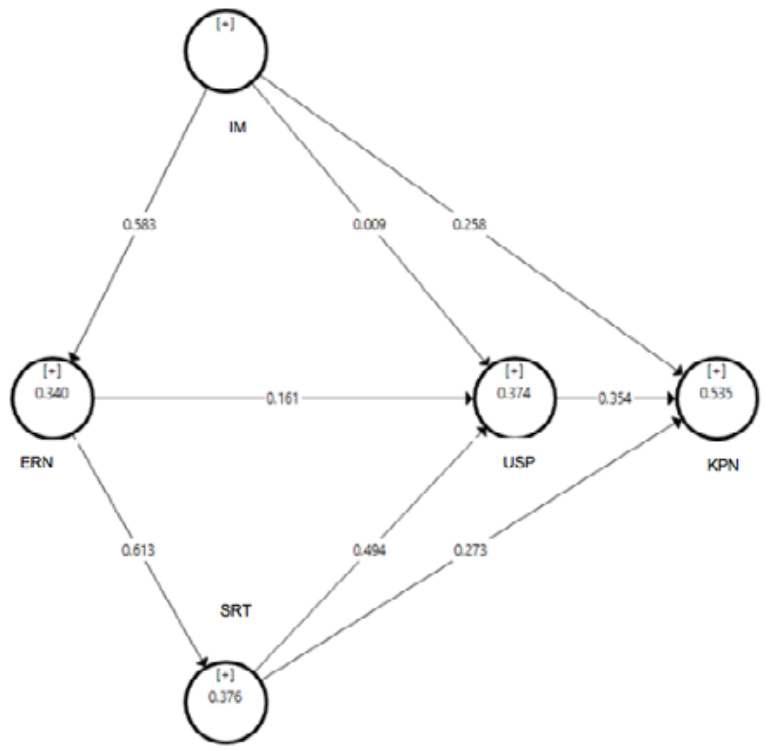

Figure 2 | University Social Responsibility Variables Model Source: Personal elaboration in Smart PLS, V. 3.0, based on field information. 
In Figure 1, the structural model is seen in graphic form and represents the relationships between constructs that are hypothesized in the proposed model. To analyze the structural model with PLS a recursive model is needed, meanings that loops are not allowed in structural relationships. Because the primary objective of the PLS is prediction, the accuracy of the model is evaluated by two main indices: the coefficients of the structural paths and the combined predictivity $\left(R^{2}\right)$ of the endogenous constructs (CHIN, 2010). (DUARTE; RAPOSO, 2010), used the criterion that the explained variance $\left(\mathrm{R}^{2}\right)$ for endogenous variables must be greater than 0.1 .

In Figure 2, the evaluation of the coefficients path described that these coefficients have standardized values, approximately between -1 and +1 . Coefficients closer to +1 indicate a strong positive relationship, in contrast to -1 , while coefficients close to 0 indicate weakness with no significance. Table 5 describes the relationships between the constructs based on the coefficients path representing the hypothesized relationships between the constructs. It can be fully appreciated that the most significant relationship is the ERM variable (0.583) with the SRT variable (0.613) and the least significant relationship is that of the IM with the USP (0.009).

Table 5 | Coefficients Path

\begin{tabular}{|c|c|c|c|c|c|}
\hline & $S R T$ & IM & KPM & ERM & USP \\
\hline SRT & & & 0.273 & & 0.494 \\
\hline IM & & & 0.258 & 0.583 & 0.009 \\
\hline \multicolumn{6}{|l|}{ KPM } \\
\hline ERM & 0.613 & & & & 0.161 \\
\hline USP & & & 0.354 & & \\
\hline
\end{tabular}

Source: Personal elaboration in Smart PLS, V. 3.0, based on field information.

The coefficient of determination $\left(R^{2}\right)$ is the most used to evaluate a structural model and is a measure of the model's predictive capability. This is calculated as the square of the correlation between an endogenous construct and the predicted values. It represents the amount of variance in the endogenous construct explained by all the endogenous constructs linked to it. The values of $R^{2}$ from 0 to 1 , with levels close to the unit $\mathrm{R}^{2}$, indicate a higher level of predictive precision.

In Table 6, it is described that the KPM variable for the USR is the one that presents the highest indicators, $R^{2}$ by 0.535 and $R^{2}$ adj 0.533 , they can also be seen graphically in Figures 1 and 2 . In Table 6 , it is possible to notice that both the Cronbach's Alpha coefficient and the Composite Reliability measure are higher than 0.70 , so that each of the constructs shows validity and internal consistency. Concerning the Average Extracted Variance, two variables show a value greater than 0.53 , USR with 0.675 and ERM with 0.252 . The results show that the Structural Model have robust constructs since the validity levels are accepted and give high reliability to the values obtained by the latent variables based on the observable variables.

Table 6 | Reliability, Construct Validity and Determination $\left(R^{2}\right)$

\begin{tabular}{ccccccc}
\hline Variables & $\begin{array}{c}\text { Cronbach's } \\
\text { Alpha }\end{array}$ & rho_A & $\begin{array}{c}\text { Compound } \\
\text { reliability }\end{array}$ & $\begin{array}{c}\text { Media extracted } \\
\text { variance } \\
\text { (AVE) }\end{array}$ & $R^{2}$ & $R^{2 \text { Adjusted }}$ \\
\hline SRT & 0.788 & 0.805 & 0.843 & 0.408 & 0.376 & 0.375 \\
IM & 0.778 & 0.802 & 0.837 & 0.398 & -- & -- \\
KPM & 0.853 & 0.856 & 0.891 & 0.578 & 0.535 & 0.533 \\
ERM & 0.786 & 0.789 & 0.833 & 0.252 & 0.340 & 0.339 \\
USP & 0.838 & 0.843 & 0.892 & 0.675 & 0.374 & 0.372 \\
\hline
\end{tabular}

Source: Personal elaboration in Smart PLS, V. 3.0, based on field information. 
When performing the process of each of the indicators using the PLS-SEM technique, the factors that affect each index are shown, considering those with a total effect greater than 0.40 , as seen in Table 8 and Figure 2. Based on the previous information, the correlation of latent variables was obtained (Table 7) and the indices were grouped, resulting in the variables as observed in Table 8. In which the KPM variable for the USR as the most significant is observed since it presents a positive association with each of the independent variables ERM, IM and SRT.

Table 7 | Latent Variables Correlation

\begin{tabular}{ccccc}
\hline Variables & I & II & III & IV \\
\hline I. SRT & & & & \\
II. IM & 0.582 & & & \\
III. KPM & 0.635 & 0.555 & 0.505 & \\
IV. ERM & 0.613 & 0.583 & 0.469 \\
V. USP & 0.598 & 0.390 & 0.618 & \\
\hline
\end{tabular}

Source: Personal elaboration based on the information obtained from the fieldwork using the PLS.

For the Heterotrait-Monotrait (HTMT) measurement, the value for the relationship between KPM and SRT was 0.764, for ERM and SRT 0.761 and between KPM and USP 0.734 (see Table 9). With these values, it is considered that the indicators that make up each of the proposed variables meet the discriminant validity criteria.

Following the procedure of Hair et al. (2016), the first step is the evaluation of any sign of collinearity, for which the VIF values were used, represented in Table 10. The SRT, IM and USP constructs are predictors of the KPM construct, and all the values are below the limit value of 5 , so there is no collinearity between the constructs and thus, we can proceed to the evaluation of the structural model.

Table 8 | Affected Factors by Variable and Considered Index (total effect greater than 0.40)

\begin{tabular}{|c|c|c|c|c|c|c|c|c|c|c|c|}
\hline$K E Y$ & $S R T$ & $I M$ & KPM & $E R M$ & USP & KEY & $S R T$ & $I M$ & $K P M$ & ERM & USP \\
\hline AL1 & & 0.706 & & & & ICE5 & & & & 0.513 & \\
\hline AL2 & & 0.571 & & & & ICE6 & & & & 0.538 & \\
\hline CM1 & & & 0.812 & & & IN1 & & 0.696 & & & \\
\hline $\mathrm{CM} 2$ & & & 0.716 & & & IN2 & & 0.53 & & & \\
\hline CRS1 & 0.619 & & & & & IP1 & & & 0.764 & & \\
\hline CRS2 & 0.707 & & & & & IP2 & & & 0.799 & & \\
\hline CS1 & & & 0.783 & & & MRA1 & & & & 0.573 & \\
\hline CS2 & & & 0.681 & & & MRA2 & & & & 0.556 & \\
\hline EX1 & & & & & 0.868 & MRA3 & & & & 0.56 & \\
\hline EX2 & & & & & 0.859 & PD1 & & 0.772 & & & \\
\hline FI1 & 0.636 & & & & & PD2 & & 0.692 & & & \\
\hline $\mathrm{FI} 2$ & 0.753 & & & & & PE & & & & 0.403 & \\
\hline FM1 & 0.695 & & & & & PE2 & & & & 0.406 & \\
\hline FR1 & 0.682 & & & & & PE3 & & & & 0.535 & \\
\hline FR2 & 0.525 & & & & & RC3 & & 0.605 & & & \\
\hline FR3 & 0.434 & & & & & TCA1 & & & & 0.452 & \\
\hline ICE1 & & & & 0.439 & & TCA2 & & & & 0.498 & \\
\hline ICE2 & & & & 0.503 & & UE1 & & & & 0.569 & \\
\hline ICE3 & & & & 0.466 & & VN1 & & & & & 0.825 \\
\hline ICE4 & & & & 0.472 & & VN2 & & & & & 0.727 \\
\hline
\end{tabular}

Source: Personal elaboration based on the information obtained from the fieldwork using the PLS. 
Table 9 | Heterotrait-Monotrait Ratio (HTMT) Test Results

\begin{tabular}{cccc}
\hline Variables & SRT & IM & \\
\hline SRT & & & \\
IM & 0.725 & 0.664 & 0.609 \\
KPM & 0.764 & 0.710 & 0.734 \\
ERM & 0.761 & 0.464 & 0.723 \\
USP & 0.725 & 0 \\
\hline
\end{tabular}

Source: Personal elaboration based on the information obtained from the fieldwork using the PLS.

Table 10 | VIF Values of Structural Model

\begin{tabular}{|c|c|c|c|c|c|}
\hline Variables & $S R T$ & $I M$ & $K P M$ & $E R M$ & USP \\
\hline SRT & & & 2.002 & & 1.825 \\
\hline IM & & & 1.517 & 1.000 & 1.725 \\
\hline \multicolumn{6}{|l|}{ KPM } \\
\hline ERM & 1.000 & & & & 1.829 \\
\hline USP & & & 1.563 & & \\
\hline
\end{tabular}

Source: Personal elaboration based on the information obtained from the fieldwork using the PLS.

As for the $\mathrm{f}^{2}$ effects, values greater than 0.02 indicate there is an effect between the latent variables. In this case, it is considered the variables SRT with USP is 0.214, IM with ERM is 0.514, ERM with SRT is 0.602 , mainly, since they all have values greater than 0.02 , (see Table 11 ).

Table 11 | Efectf2

\begin{tabular}{|c|c|c|c|c|c|}
\hline Variables & SRT & $I M$ & $K P M$ & ERM & USP \\
\hline SRT & & & 0.080 & & 0.214 \\
\hline IM & & & 0.094 & 0.514 & \\
\hline \multicolumn{6}{|l|}{ KPM } \\
\hline ERM & 0.602 & & & & 0.023 \\
\hline USP & & & 0.173 & & \\
\hline
\end{tabular}

Source: Personal elaboration based on the information obtained from the fieldwork using the PLS.

\subsection{DISCUSSION OF RESULTS}

The investigation was presented with a model showing validity; therefore, the results are reliable to perceive what happens between the interaction of variables and indicators of the USR implemented in the UMSNH. The statistical description presents a quantifiable performance and the structural model is consistent with the expected results from the perception of the university actors.

The USR has been a management instrument to promote a change in socio-environmental culture and which seeks to impact society. The present work has reviewed the implementation of the USR in the UMSNH evaluated from the actors' perception through five years. The overall average performance was fair, with values close to 3 out of 5 possible points. This implies that in the Nicolaitas global perception, the USR has provided regular, rather than good or excellent results.

One of the most relevant results is shown in Table 8, indicating the impact that each index had per variable. For example, for SRT two indicators showed greater relevance: CRS2 and FR1, and significant relevance: FI1, FI2, FM1, FR2, FR3, CRS1. This is important when evaluating the aspects that should be strengthened to improve the USR and the type of expected effect. 
Another element that provides valuable information for the USR is that three variables have the greatest directional impact on the entire model, these being: SRT, IM and KPM, which can help to improve the results of the USR's implementation to impact ERM and USP more efficiently, suggesting that, to have better results in the performance of the USR, the performance in these three variables is fundamental; more so, the performance in the most influential indicators.

The objectives set for quantifying the variable performance on the USR and the impact of each variable served for measuring the relationships between the indicators and the variables. At the level of the variable interaction, the IM has a directional impact on the ERM both variables are operative, meaning highly visible in practice, which may explain the direction and intensity of the impact.

One of the most heterogeneous indicators is the USR training, in which authority appears high and with a wide difference with the administrative staff and professors. It can also be noticed that the sectors with the highest variance were AUT and ST, which suggests a very different perception of both sectors that may also denote a bias in the responses, given their political pose. Which represents one of the job's weaknesses.

It also highlights that the SRT has a relatively considerable impact on the USP since it deals with bounding and university extension with the environment. At the same time, the SRT impacts the KPM, although to a lesser extent. As expected, the KPM is directly impacted by three paths with the variables USP, SRT and IM; this would be explained because the generated knowledge is directly related to academic training, university policy and the university projection. In summary, the trials show expected relationships, however; low coefficients would indicate a regular performance of the USR.

The low value for USP would reflect the lack of bonding with the outside, a not isolated situation in the Ibero-American universities that have implemented the USR and maintain the practices in diverse social environments, as one of their main challenges, relating their policies to the problems in their communities, (AYALA-RODRÍGUEZ et al., 2010). This implies considering Higher Education a common good, incorporating the stakeholders into the governance, and including in its action focus not moving away from its immediate reality, in the search for an international ranking (MARTÍ-NOGUERA; LICANDRO; GAETE-QUEZADA, 2018).

An unresolved aspect in the exploration of the results is the expectation and monitoring of the patterns that the USR instils on the actors involved outside of the university campuses. As shown by some studies around, graduate students give high importance to USR in their expectations and it may influence behaviours and inclusion of categories and topics related to ethics, environment and sustainable development (ESPITIA-CUBILLOS; MENESES-PORTELLA; HUERTAS-FORERO, 2020). Thus, the results show the interaction between the variables from the perspective of the actors, but it is still pending to complement the perceptions from the thematic categories; especially for the academic community.

It should also be noted that the response of universities to the current socio-environmental crisis finds conceptual and practical support in the USR which constitutes an important challenge because it touches sensitive fibres in different dimensions of the process. It ranges from the production of knowledge and the "hidden" curriculum to teaching methods and formal content (ARANGO et al., 2014; CHIRINOS; PÉREZ, 2016; GASCA; OLVERA, 2011; NÚÑEZ, 2013; RODRÍGUEZ et al., 2020; VALLAEYS, 2013; YURÉN; GARCÍA; BRISEÑO, 2019). As could be seen in the case study, a change in behaviour is slow and implies strategies that seek synergies to improve performance, in the beginning, the main variables (such as $\mathrm{IM})$, but then it is necessary to insist on the approach of new paradigms beginning with knowledge and followed by example, in the adoption of standards, which are not always popular at first.

Another aspect the USR explores is its function as a binding axis with social environment involving a variety of elements from consulting and technology transfer (MARTíNEZ DE CARRASQUERO et al., 2008); and the USR as social innovation (AGUIRRE; GÓNZALEZ, 2020); to the university role as a stakeholder, transmitting the concerns to all the areas of influence, not only employees, (professors 
and administrative staff) and students (clients), but also the suppliers of material goods, services and financing (CONTRERAS; ANDRADE, 2012; GÓMEZ; NAVEIRA; BERNABEL, 2018). This is an aspect gaining importance, but it still faces barriers in the comprehensive implementation. However, in the sectors with direct involvement; (professors, researchers, authorities and administrative staff -employees- and clients -students-) there is a promising and favourable perspective.

\section{CONCLUSIONS}

The Policy regarding the installation of the USR management model has been around for five years at the time of performing this study and ten years since the Institutional Environmental Plan set the antecedent on environmental management in the UMSNH. The USR goes beyond the approaches on environmental management, covering areas such as principles of identity, social projection, organizational structure, democracy, freedom and gender equality. But the main focus is the role that the university plays in society. As can be denoted, progress has been made, but it is still necessary to continue improving this aspect.

The performance regarding the implementation of the USR in the UMSNH was regular, implying that there are still areas of opportunity to attend and improve. These areas can be found in the structural analysis. As expected, IM turns out to be a key variable in the model behaviour since it directly impacts ERM and KPM as well as SRT indirectly. Likewise, the most important management indicator was the labour environment. All that is present in knowledge-based societies and ecosystems. In this sense, the actions that impact this variable (particularly the AL1 indicator) will have an important effect on the behaviour of the model. As an area of opportunity, AL2 remains pending to improve its attentiveness.

One of the contributions of this work was to analyze the USR performance in the UMSNH, from a relatively new SEM-PLS Model. The results have shown the relationship between the variables and their expected behaviour. This model was represented by the constructs of five variables and 17 indicators.

The Cronbach's Alpha and Composite Reliability tests result established that each of the constructs showed validity and internal consistency. The most significant relationship was presented between the variables: ERM with SRT (0.613) and the least significant relationship is found between the IM variable with USP (0.009). From the Determination Coefficient calculation, it was possible to establish KPM for the USR being the one with the highest indicators, the R2 by 0.535 and the R2adj 0.533 .

The variables ERM, SRT and KPM, showed the highest impacts and the greatest interaction in the USR. While the USP and the IM show areas of opportunity. Specifically, it could be denoted for each indicator in Figure 1, which summarizes the PLS-SEM result.

Among the limitations of the study and a pending research line, are the lack of representation of those who do not directly belong to the university (graduate students, independent professionals, companies, government and civil society). In this sense, the existence of a response bias regarding the actors participating in the research is likely.

The role of universities towards sustainable development is still a road under construction, however, efforts such as the USR policies show firm elements of progress in institutional commitment. Nonetheless, these measures have yet to be generalized and internalized in the communities so that their impact may become more noticeable. Once the USR in the UMSNH was analyzed we could see the most important variables to promote a higher positive impact in the USR. At the same time, we can notice the differences in perceptions among the university sectors, which should be considered in the monitoring strategy of the USR.

We, the authors, declare to have no conflict of interest when presenting the results of this research. 


\section{REFERENCES}

ABADIA, J. M. M.; VALLESPÍN, E. M. Universidad y Desarrollo Sostenible: análisis de la rendición de cuentas de las universidades públicas desde un enfoque de responsabilidad social. Revista Iberoamericana de Contabilidad de Gestión, v. 10, n. 19, p. 1-18, 2012.

AGUIRRE, Á. S.; GONZÁLEZ, J. C. La innovación social como un eje articulador de la tecnología y la responsabilidad social en un contexto universitario. Caso de estudio a partir del diseño y fabricación de prótesis de mano para niñas y niños preescolares. Revista Espacios, v. 41, n. 06, 2020.

ARANGO TOBÓN, O. E. et al. Formación Académica, Valores, Empatía y Comportamientos Socialmente Responsables en Estudiantes Universitarios. Revista de La Educación Superior, v. 43, n. 169, p. 89-105, 2014. DOI: https://doi.org/10.1016/j.resu.2015.01.003.

ASOCIACIÓN DE UNIVERSIDADES JESUÍTICAS DE LATINOAMÉRICA. Políticas y Sistema de Autoevaluación y Gestión de la Responsabilidad Social Universitaria. AUSJAL. Ed. Editorial de la Universidad Católica de Córdoba. 2014.

AYALA-RODRÍGUEZ, N. et al. Social transcultural representations about the concept of university social responsibility. Studies in Higher Education, p. 1-15, 2017. DOI:10.1080/03075079.2017.1359248

BATISTA-FOGUET, J. M.; COENDERS, G. Modelos de Ecuaciones Estructurales. Ed. La Muralla. Madrid, España. 2000. ISBN: 84-7133-694-4

CANTÚ, M. P. C. Las Instituciones de Educación Superior y la Responsabilidad Social en el Marco de la Sustentabilidad. Revista Electrónica Educare, v. 17, n. 3, p. 41-55, 2013.

CHIN, W. W. How to Write Up and Report PLS Analyses. In: ESPOSITO VINZI, V. et al. (Ed.). Handbook of Partial Least Squares: concepts, methods and applications, p. 655-690, 2010. Berlin, Heidelberg: Springer Berlin Heidelberg. DOI: https://doi.org/10.1007/978-3-540-32827-8_29

CHIRINOS, V. A.; PÉREZ PERALTA, C. M. La Responsabilidad Social Universitaria: emprendimiento sostenible como impacto de intervención en comunidades vulnerables. Revista Ean, v. 81, p. 91-110, 2016.

CONTRERAS, F. G.; ANDRADE, E. N. Universidades privadas y su responsabilidad social en Chile: un estudio exploratorio. Revista de Ciencias Humanas y Sociales, n. 68, 243-256, 2012.

DUARTE, P. A. O.; RAPOSO, M. L. B. A PLS model to study brand preference: an application to the mobile phone market. In: Handbook of partial least squares, p. 449-485, 2010. Springer, Berlin, Heidelberg.

ESCUTIA, F. R. Universidad Pública y Sustentabilidad. Entre el discurso contemporáneo y la práctica formativa. En Memoria: In Memorias del I Congreso Iberoamericano de Ciencia, Tecnología, Sociedad e Innovación CTS, v. 1, 2006. Chiapas, México.

ESPITIA-CUBILlOS, A. A.; MENESES-PORTELA, L. I.; HUERTAS-FORERO, I. Análisis de las expectativas de los egresados frente a un modelo de responsabilidad social universitaria. Equidad y Desarrollo, n. 35, 2020. DOI: https://doi.org/10.19052/eq.vol1.iss35.3

FUENTES, G. R. H.; VALLAEYS, F.; CASTRILLÓN, M. A. G. El aprendizaje organizacional como herramienta para la universidad que aprende a ser responsable socialmente. Pensamiento Americano, v. 11, n. 20, 2018. DOI: http:// dx.doi.org/10.21803\%2Fpenamer.11.20.499

GARCÍA, R. F.; AGUILAR, A. R. Los universitarios trabajando por un futuro equitativo, justo y sostenible. Universidad Michoacana de San Nicolás de Hidalgo. Michoacán, México, 2017. 
GARCÍA, E. S.; GARCÍA, R. F. La Responsabilidad Social en las Universidades Mexicanas (IESALC-ORSLC - OMERSU). Universidad Michoacana de San Nicolás de Hidalgo. Michoacán, México, 2014.

GASCA, P.; OLVERA, J. C. Construir ciudadanía desde las universidades, responsabilidad social universitaria y desafíos ante el siglo XXI. Convergencia: revista de Ciencias Sociales, v.18, n. 56, 2011.

GÓMEZ, L. M.; NAVEIRA, Y. A.; BERNABEL, A. P. Implementing University Social Responsibility in the Caribbean: perspectives of internal stakeholders. Revista digital de investigación en docencia universitaria, p. 101-120, 2018.

GONZÁLES, A. J. A.; PAZMIÑO, S. M. Cálculo e interpretación del Alfa de Cronbach para el caso de validación de la consistencia interna de un cuestionario, con dos posibles escalas tipo Likert. Revista Publicando, v. 2, n. 1, p. 62-77, 2015.

HAENLEIN, M.; KAPLAN, A. M. A beginner's guide to partial least squares analysis. Understanding statistics, v. 3, n. 4, p. 283-297, 2004.

HAIR JÚNIOR, J. F. et al. A primer on partial least squares structural equation modeling (PLS-SEM). Sage Publications, 2016.

IESALC, I. I. La responsabilidad de la universidad en el proyecto de construcción de una sociedad. Revista Educación Superior y Sociedad. 206, 2008. ISSN: 0798-1228.

IZARRA, V. D. A. Entre la Desmoralización y el Bienestar: obstáculos para la formación de un docente con valores profesionales. En: Ética Profesional y Responsabilidad Social Universitaria. Experiencias Institucionales. HIRSH, A. A.; PÉREZ-CASTRO, J. (Coord.) Ed. UNAM, México, 2019. ISBN 978-607-30-2493-8.

LEFF, E. Saber Ambiental: sustentabilidad, racionalidad, complejidad y poder. Siglo XXI. 2002.

LIMO S. G.; PEÑA, A. D. H. El impacto de la responsabilidad social universitaria en la cultura organizacional de las universidades privadas en Lima Metropolitana. Tesis de la UPC, Perú, 2019. Available in: http://hdl.handle. net/10757/648669.

LOEHLIN, J. C. Latent variable models: an introduction to factor, path, and structural analysis. Lawrence Erlbaum Associates, Inc. 1987.

LÓPEZ, M. T. V.; LÓPEZ, M. V. Los comienzos de la RSU en la UMSNH (México). Sistema Iberoamericano de Responsabilidad Social Empresarial. Universidad de Castilla. La Mancha, 2016. Available in: http://sirse.info/wpcontent/uploads/2016/03/RSU-UMSNH-VIZCA\%C3\%8DNO-L\%C3\%93PEZ-publicac.pdf. 3 de marzo de 2017.

MARTÍ-NOGUERA, J. J.; LICANDRO, Ó.; GAETE-QUEZADA, R. La responsabilidad social de la educación superior como bien común. Concepto y desafíos. Revista de la educación superior, v. 47, n. 186, p. 1-22, 2018.

MARTÍNEZ, A. J. Conflictos ecológicos y justicia ambiental. Papeles de relaciones ecosociales y cambio global, $n$. 103, p. 11-28, 2008.

MARTÍNEZ DE CARRASQUERO, C. et al. La responsabilidad social universitaria como estrategia de vinculación con su entorno social. Frónesis, v. 15, n. 3, p. 81-103, 2008.

MCKEOWN, R. et al. Manual de educación para el desarrollo sostenible. Centro de Energía, Medio Ambiente y Recursos, Universidad de Tennessee, 2002. Available in: http://www.iiap.org.pe/Upload/Publicacion/PUBL454.pdf 
MURGA-MENOYO, M. Á. La Carta de la Tierra: un referente de la década por la educación para el desarrollo sostenible. Revista de educación, n. 1, p. 239-262, 2009.

PÉREZ, J. D.; VALLAEYS, F. Prácticas y modelos de la Responsabilidad Social Universitaria en México. Ed. ANUIES. México, 2016.

QUINCHE-MARTíN, F. L.; CABRERA-NARVÁEZ, A. Exploring the Potential Links between Social and Environmental Accounting and Political Ecology. Social and Environmental Accountability Journal, v. 40, n. 1, p. 53-74, 2020.

RAMOS, J. et al. La Formación en Responsabilidad Social y su Impacto en Diversas Carreras Universitarias. Revista de Investigación Educativa, v. 34, n. 2, p. 435-451, 2016. 10.6018/rie.34.2.244271.

RODRÍGUEZ, S. Y. L. et al. Responsabilidad Social Universitaria: transversalidad y desarrollo sostenible en Latinoamérica. Revista of business and entrepreneurial studies, p. 328-340, 2020. DOI: https://doi.org/10.37956/ jbes.v4i2.69.

ROLDÁN, J. L.; SÁNCHEZ-FRANCO, M. J. Variance-based structural equation modeling: guidelines for using partial least squares. Information Systems Research, in Research Methodologies, Innovations and Philosophies in Software Systems Engineering and Information Systems, p. 193-221, 2012.

TOMMASINO, H.; FOLADORI, G.; TAKS, J. La crisis ambiental contemporánea. Sustentabilidad, p. 9-26. In: NAINA, P.; FOLADORI, G. (Ed.) ¿Sustentabilidad? Desacuerdos sobre el desarrollo sostenible. Montevideo: Trabajo y Capital, 2001, p. 11-26, 2001.

VALLAEYS, F. La responsabilidad social de la Universidad. Palestra portal de asuntos públicos de la PUCP, 2013. Available in: http://repositorio.pucp.edu.pe/index/bitstream/handle/123456789/11974/responsabilidad_ social_Vallaeys.pdf?sequence=1\&isAllowed=y

VALLAEYS, F. La responsabilidad social universitaria: un nuevo modelo universitario contra la mercantilización. Revista Iberoamericana de Educación Superior, v. 5, n. 12, p. 105-117, 2014.

VALLAEYS, F. Responsabilidad Social Universitaria ¿Cómo entenderla para querer practicarla? Blog de ética RSU. Pontificia Universidad Católica de Perú, 2014. Available in: http://blog.pucp.edu.pe/item/16770.

VALLAEYS, F. ¿Por qué la Responsabilidad Social Empresarial no es todavía transformadora? Una aclaración filosófica. Andamios, v. 17, n. 42, p. 309-333, 2020. DOI: http://dx.doi.org/10.29092/uacm.v17i42.745.

VALLAEYS, F.; CARRIZO, L. Hacia la construcción de indicadores de responsabilidad social universitaria. Pontificia Universidad Católica del Perú (PUCP), 2006.

VALLAEYS, F.; DE LA CRUZ, C.; SASIA, P. M. Responsabilidad Social Universitaria: manual de primeros pasos. InterAmerican Development Bank, 2009.

VÁZQUEZ, J. L.; AZA, C. L.; LANERO, A. University social responsibility as antecedent of students' satisfaction. International Review on Public Nonprofit Marketing, n. 13, p. 137-149, 2016. DOI: https://doi.org/10.1007/ s12208-016-0157-8

YURÉN, T. et al. Principios Éticos para la Formación Centrada en el Aprendizaje. In: HIRSH, A. A.; PÉREZ-CASTRO, J. (Coord.). Ética Profesional y Responsabilidad Social Universitaria. Experiencias Institucionales. Ed. UNAM, México. p. 115-131, 2019. 